\title{
Editorial
}

\section{Place your bets!}

\author{
Carlos Renato Zacharias
}

\section{International Journal of High Dilution Research}

Place your bets! A new year is coming! It seems unbelievable, but when 2009 has seemingly only just begun, in fact it is almost running out! I know that time does not hearken to our wishes, but besides being aware of its passing, cannot we challenge it?

Re-reading the editorials written for IJHDR in 2009, I realized that time is our friend. We started 2009 paraphrasing the slogan of the Astronomical International Year, inviting everyone to discover the phenomenon of HDs [1], and noting that this emergent field follows steps similar to other fields of science, which have also faced methodological and conceptual challenges. This same editorial stated that, unlike the astronomical community, we were still disorganized on a global scale, despite local efforts. In another editorial, we played with time, but without losing the awareness that our current actions can shape the future [2]. Reflecting on our past, searching for hidden truths and partially revealed mysteries, we were indeed starting to build 2010. And in this process of reflection and search for new knowledge, we began to reflect on where we were going to [3] to realize that at this time, more important than knowing where to go, is the realization that we must keep together, uniting and sharing efforts, ideas and insights.

Looking back at the results achieved in 2009, we realized that time is not as cruel as it seems, nor so fast! IJHDR achieved the recognition of the scientific community, attained its first international indexations - while the process for is already in progress - as a result of the collective effort of editors, authors and readers.

The scientific and technological innovations, as well as the multidisciplinary scope of HDs were evident in the issues published during 2009. And the current issue is no exception! In the area of basic research, Bonamin et al [4] provide an experimental model fit to disclose the adverse effects caused by HDs during pregnancy and fetal development of mice. In the clinical area, Teixeira [5] discusses epidemics and so-called "epidemic genius", while Adler et al [6] present results of the standardization, educational and therapeutic use of fifty-milesimal potencies (LM or Q). In veterinary area, Coelho et al [7] present an application of HDs to the production of swine, with great importance for the productive sector and strong technological potential. Finally, Zacharias et al [8] introduce a scientific network with the goal of joining researchers dedicated to HDs.

Therefore, when looking back at 2009, we see that, despite many difficulties, we managed to grow while remaining consistent with our focus and mission. But for all the achievements of the past, I still prefer to reinvent the future [2]. I do not want to stand idly by, waiting to see what the future holds, but to prepare the future for new conquests. I have already placed my bets!

2010 will begin with the publication of a special issue, in the journal Homeopathy [9], dealing with biological models for HDs. Soon after, in April, it will follow the GIRI meeting [10], in Monaco, an unique opportunity to bring together the leaders in research in HDs. In the second semester, IJHDR will publish a special issue devoted to critical analysis of Hahnemann's Organon, celebrating the 200th anniversary of its first edition. Thus, the agenda for 2010 is full and will be very interesting. And certainly both researchers and skeptics will have much work to "digest" all this information. I bet that 2010 will be a time for very rich discussion and a period of transition in the organization of our scientific community. 
Place your bets for 2010! But remember to run to meeting them, because I'm already running!

\section{References}

[1] Zacharias CR. The High Dilution phenomenon, Yours to Discover. [Editorial]. Int J High Dilution Res [online]. 2009 [cited 2009 Dec 15]; 8(26): 1-2. Available from:

http://www.feg.unesp.br/ ojs/index.php/ijhdr/article/view/331/378

[2] Zacharias CR. Back to the Future [editorial]. Int J High Dilution Res [online]. 2009 [cited 2009 Dec 15]; 8(27): 40-40. Available from: http://www.feg.unesp.br/ ojs/index.php/ijhdr/article/view/338/385

[3] Zacharias CR. Where we are going to? [editorial]. Int J High Dilution Res [online]. 2009 [cited 2009 Dec 15]; 8(28): 80-81. Available from: http://www.feg.unesp.br/ ojs/index.php/ijhdr/article/view/355/398

[4]leoni

[5]zulian

[6]ubiratan

[7] cideli

[8] renpad

[9] Homeopathy

[10] GIRI - Groupe International de Recherche sur l'Infinitésimal. France; 1987 [cited 2009 Nov 13]. Available from: http://www.giriweb.com

\section{(c)) BY-NC-ND Licensed to GIRI}

How to cite this article: Zacharias CR. Place your bets! [editorial]. Int J High Dilution Res [online]. 2009 [cited YYYY Month dd]; 8(29): 144-145. Available from: http://www.feg.unesp.br/ ojs/index.php/ijhdr/article/view/355/398. 